\title{
Evaluation and Selection of Physical Soil and Water Conservation Techniques for Early Mature Sorghum Root Zone Moisture Retention at Harari, Erer Research Station
}

\author{
Robe Elema*, Hussein Abiro, Sisay Negash \\ Oromia Agricultural Research Institute, Fedis Agricultural Research Centre, Harar, Ethiopia \\ Email address: \\ robeelma663@gmail.com (R. Elema) \\ ${ }^{*}$ Corresponding author \\ To cite this article: \\ Robe Elema, Hussein Abiro, Sisay Negash. Evaluation and Selection of Physical Soil and Water Conservation Techniques for Early Mature \\ Sorghum Root Zone Moisture Retention at Harari, Erer Research Station. Journal of Water Resources and Ocean Science. \\ Vol. 10, No. 3, 2021, pp. 39-45. doi: 10.11648/j.wros.20211003.11
}

Received: February 5, 2021; Accepted: May 21, 2021; Published: May 27, 2021

\begin{abstract}
The experiment was conducted at Babille district, during 2018 and 2019 main cropping season at Erer Research Station. Erer research sub site is located latitude of $09^{\circ} 10^{\prime} 41.5^{\prime \prime}$ north and longitude of $042^{\circ} 15^{\prime} 27.3^{\prime \prime}$. The objectives of the experiments were to evaluate and select best methods of root zone moisture retention and soil conservation techniques suited for early mature sorghum. The treatments of experiments were, Control (no soil and water conservation measures), open ended tied ridge, level soil bund, contour furrow, closed ended tied ridge, Broad bed, Semi-circular and mulch respectively. The design of the experiment was RCBD with three replication. Genstats $18^{\text {th }}$ editions was used for data Analysis. Statistically there is highly significant variation among the treatments in terms of all parameters at 5\% significance level across three planting years. First year, the highest plant height was obtained from the treatment with Broad bed followed by closed ended tied ridge. On other hand, the lowest plant height was recorded from the treatments with soil bund followed by control (no conservation structure). This is because of no more top fertile soil disturbance during first year. During the second and third planting year, the highest, plant height $(132.86 \mathrm{~cm})$ and the longest panicle diameter $(6.5)$ was recorded, from the treatments with open ended tied ridge, followed by soil bund and contour furrow respectively. That was because of soil and water conservation (swc) structures design and extra moisture harvested in those structure than rest treatments. During the first year of the experiment, the highest grain yield was obtained from the mulch followed by open ended tied ridge treatments. This is because of no and slight top soil disturbance during the construction stage. But, the third year, the maximum grain yield was recorded from contour furrow followed by open ended tied ridge $\left(2130.9\right.$ and $\left.2000 \mathrm{~kg} \mathrm{ha}^{-1}\right)$ respectively. The lowest yield was obtained from no conservation measures followed by mulching (1125 and $1232.1 \mathrm{~kg} \mathrm{ha}^{-1}$ ). The most probable reason for this variation can be due to the amount of the moisture harvested in the root zone of sorghum because of conservation structure. So contour furrow and open ended tied ridges are suitable swc measures for the area.
\end{abstract}

Keywords: Swc-Physical, Soil and Water Conservation, Sorghum, Moisture, Contour Furrow

\section{Introduction}

It has been estimated that, a sixth of the world's land area, nearly 2 billion hectares, is now degraded as a result of overgrazing and poor farming practices. Water resources for agricultural purposes are getting scarce, and there are hardly any land reserves to be brought into production to widen the agricultural base. By 2025, close to three billion people in 48 countries will be affected by critical water shortage for all or part of the year. Agriculture is the main economic activity in sub-Saharan Africa (SSA) supporting over $67 \%$ of the population, out of which $60 \%$ depends on rain fed agricultural practices contributes to Gross Domestic Product [15]. However, rainfall is poorly distributed in these countries [10]. High losses occur due to high surface runoff during high intensity rains, poor crop rooting conditions, past and present soil erosion and evaporation losses from soil, and crop canopy [14]. Uncontrolled runoff can cause damaging 
flash floods; severe erosion; increased water turbidity.

Water is the most limiting factor for agricultural production in these regions and the low annual rainfall is often a major reason for food insecurity. Poor yields together with a large population growth have often led to severe food shortages. Generally the soil can not absorb the amount of water which falls in such a short time, causing intense surface runoff. This climatic factors means that it is important to use the limited amount of rainfall as efficiently as possible. By increasing soil water content supply and retention, crop yields can be improved significantly, and successful crop production can be made possible even in areas of very limited production potential [19].

Increasing water availability for crop production can be achieved by irrigation, but due to the lack of available water resources this is not often an option in arid regions of Ethiopian dry lands. A more realistic option is to try and utilize rainfall amounts as efficiently as possible for crops. In the arid, regions where access to irrigation and insufficient rainfall is prevailing to meet the water demands of crops, water can be harvested in order to increase the available water for crops. Water harvesting and soil moisture retention are cheap and simple options for increasing soil moisture. Water harvesting makes use of surface runoff for productive purposes, while soil moisture retention aims at preventing runoff and keeping rainwater as much as possible in place where it falls [3]. In-situ water harvesting techniques such as contour furrow, tied ridges and closed ended tied ridges improve soil moisture stored within the root zone, improve the agronomic components and produce higher grain yields [7]. Tied ridges or basins are a variation of the ridge and furrow system in which cross-ties are constructed at intervals across the furrows. The cross ties retain rainwater by restricting lateral flow of the accumulated runoff and so allow longer time for infiltration. By constructing the cross ties lower than the ridges, excess accumulated runoff can drain away. Contour ridges are, small earthen banks, with a furrow (ridges) on the higher side which collects runoff from the catchment area between the ridges. The catchment area is left uncultivated and clear of vegetation to maximize runoff.. Plants with high water requirements, such as cereal crops such as maize and sorghum are usually planted on the ridges. Sorghum one of the most important cereal crops of the tropics grown extensively over wider areas with elevation range from 1400 to 2100 meters above sea level (m.a.s.1). Its ability to adapt to adverse environmental conditions has made sorghum a popular crop worldwide. It is the major source of energy and protein for millions of people living in semi-arid tropical Africa and Asia. It remains to be the primary source of food in Ethiopia where poor harvest due to drought is common [6].

Basic bottle neck moisture stress is the major hazards that affect the livelihood. Moisture stress affects crops in the livelihood zone every year either due to inadequate rainfall (in terms of total volume) or due to irregular distribution of showers during the growing period [20]. Disruptions in the amount and regular pattern of rainfall significantly affect crop production. Rainy season lasts for about one and a half months and a long rainy season that lasts for more than two months. Even though, the rainfall pattern is not easily predictable and has shown yearly fluctuations. Due to the rainfall pattern, Babile district is considered as food insecure. Though the area is moderately productive for agriculture, moisture stress contribute to lowered productivity in the area. Therefore to combat the hazard and food insecurity, the best way is enforcing existing rain drop harvesting technique like in-suit water harvesting and soil conservation by incorporating improved sorghum variety is uncompressible solution. Consequently, the Evaluation and Selection of different physical soil and water conservation measures for early mature sorghum root zone moisture retention at Harari regional state, Erer research station was initiated with the objectives of evaluate and select best methods of root zone moisture retention and soil conservation techniques suited for early mature sorghum and compare effects of selected soil and water conservation techniques on yield and yield components early maturing sorghum.

Objectives

1. To evaluate and select best methods of root zone moisture retention and soil conservation techniques suited for early maturing sorghum

2. To identify effects of soil and water conservation measures on yield and yield components of early maturing sorghum.

\section{Material and Methods}

\subsection{Description of Study Area}

The experiment was conducted at Babille district, Erer research station for three consecutive growing years of 2017 , 2018 and 2019. The agro-climatic condition of the area is semi-arid, Arid. Erer research sub site is geographically located at latitude of $09^{\circ} 10^{\prime} 41.5^{\prime \prime}(\mathrm{N})$ and longitude of $042^{\circ}$ $15^{\prime} 27.3^{\prime \prime}$ east, and the area is in the vicinity of extreme lowlands in the range of altitude of $1200-1300 \mathrm{~m}$. The area is also characterized by very short rainy season of 3 to 4 months (single quarter of the year), with all its intermittent condition and erratic distribution. Even though, the rainfall pattern is not easily predictable and has shown yearly fluctuations. Due to the rainfall pattern, the woreda is considered food insecure. The annual maximum and minimum temperatures are 26 and $20^{\circ} \mathrm{C}$, respectively, and the mean annual temperature was $24^{\circ} \mathrm{C}$. The soil is clay loam in texture and medium in organic matter content and high in exchangeable potassium.

\subsection{Experimental Design and Treatments}

The experimental design was laid out in Randomized Complete Block Design (RCBD) with three replication. The improved and early mature Melkam sorghum variety was used. The area of plot size $10 \mathrm{~m} \times 9 \mathrm{~m}\left(90 \mathrm{~m}^{2}\right)$ at spacing of $75 \mathrm{~cm}$ by $30 \mathrm{~cm}$. Distance between plot and block were $1 \mathrm{~m}$ and $2 \mathrm{~m}$, respectively. The experiment consisted of eight 
treatments, seven type of moisture conservation structure and control (without conservation structure). Test treatments are open ended tied ridge, soil bund, contour furrow, closed ended tied ridge, Broad bed, Semi-circular, mulching and control. Those physical soil and water structures were constructed based on [1] manual and Ethiopia soil and water conservation guideline with some modification to fit the soil, slope and site of the experiment. Data Collection, Soil Sampling and Statistical Data Analysis. Treatment effect was determined using plant height, panicle length, above ground biomass and grain yield. Composite soil sample was collected from (0-20 spots) before planting in zigzag movement with the sampling depth of $0-20 \mathrm{~cm}$, Soil sample after harvest was collected from every plot (at 5 spots /auger points) and analyzed for soil physio-chemical properties. Soil moisture content also recorded at planting time as well as at different growth stage of sorghum.

\subsection{Data Analysis}

Analysis of variance was performed using the GLM procedure of SAS Statistical Software Version 9.1. Effects were considered significant in all statistical calculations when the P-value was $<0.05$. Means were separated using Least Significant Difference (LSD) test.

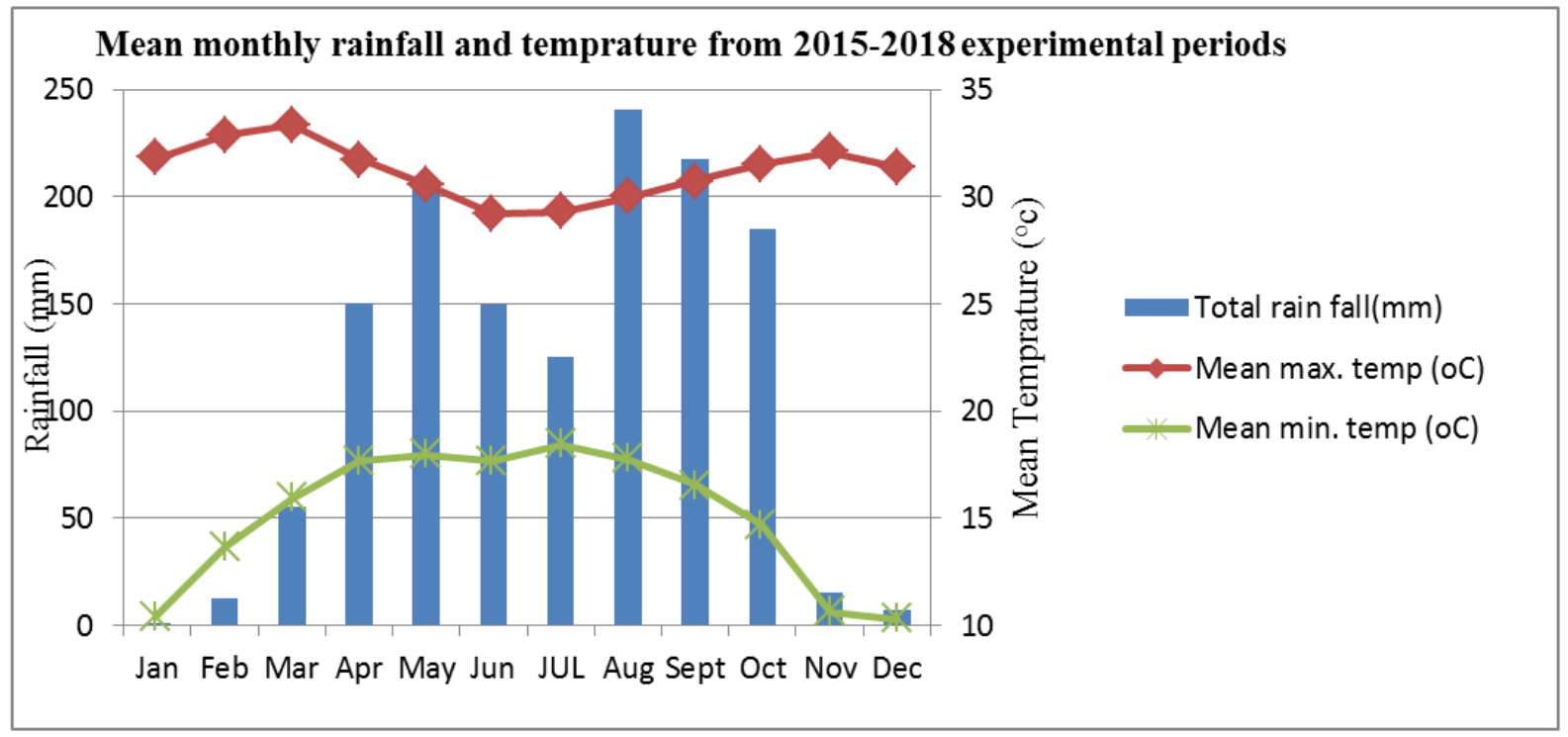

Figure 1. Mean monthly rainfall and temperature during experimental period of Erer, based on 2017-2019 meteorological data at Fadis Agricultural Research Center.

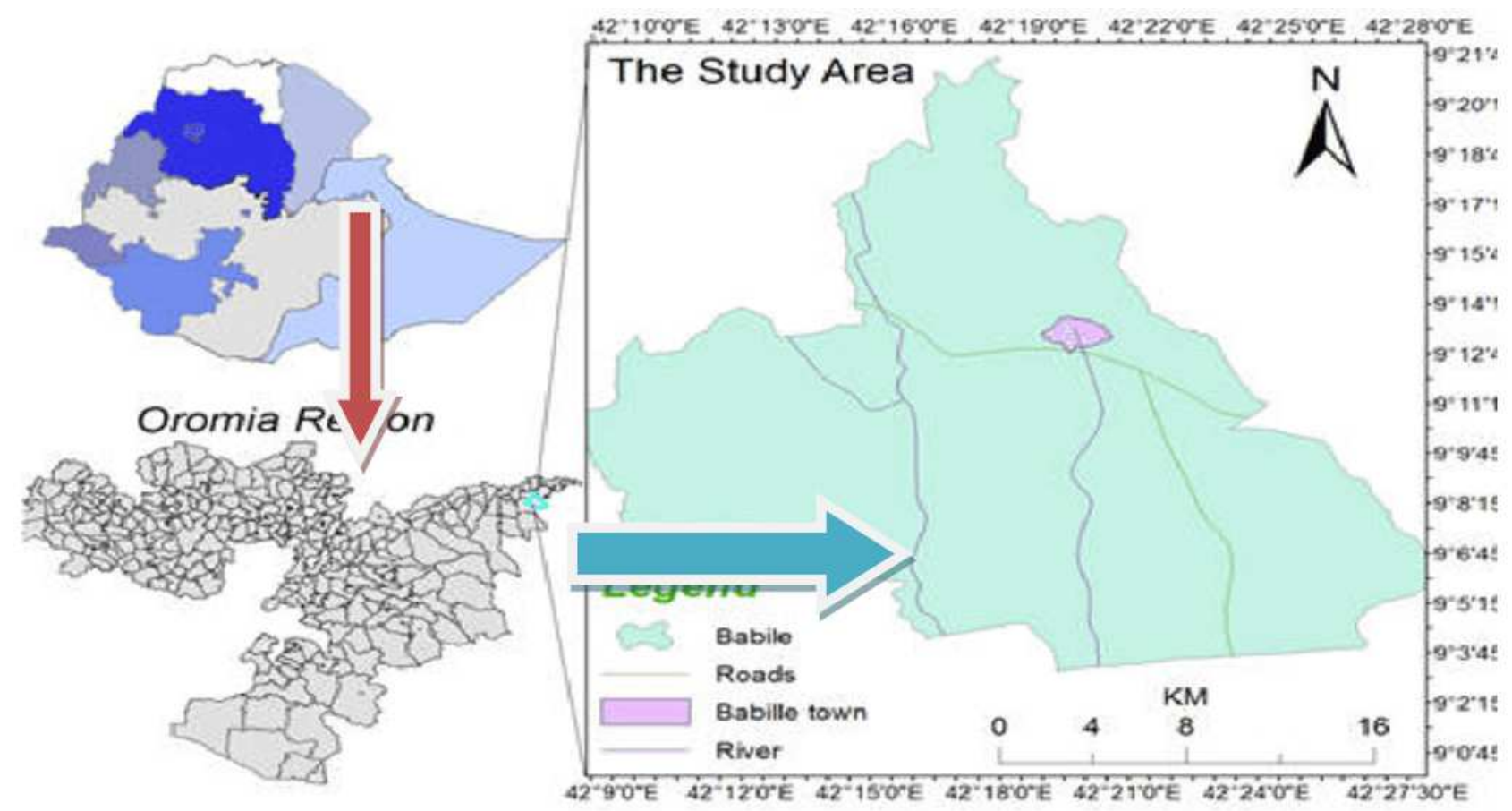

Figure 2. Map representing the study area (Babille District). 


\section{Result and Discussion}

\subsection{Soil Analysis}

Table 1. Soil physic- chemical properties of Erer.

\begin{tabular}{|c|c|c|c|c|c|c|c|c|c|c|c|c|}
\hline $\begin{array}{l}\mathbf{P} \\
\left(\mathrm{H}_{2} \mathrm{O}\right)\end{array}$ & $\begin{array}{l}\text { E.C in } \\
\text { mmhos/cm }\end{array}$ & MCF & $\% \mathrm{TN}$ & $\% \mathrm{C}$ & $\begin{array}{l}\mathbf{P} \\
\text { (ppm) }\end{array}$ & $\begin{array}{l}\text { Exch. K } \\
(\operatorname{cmol}(+) / k g \text { soil })\end{array}$ & $\begin{array}{l}\text { Exch. } \\
\mathrm{Na}(\mathrm{cmol}(+) / \mathrm{kg} \\
\text { soil) }\end{array}$ & $\begin{array}{l}\text { CEC (meq/100g) } \\
\text { soil) }\end{array}$ & Sand \% & Clay \% & Silt \% & Classification \\
\hline 7.83 & 2.746 & 1.111 & 0.070 & 1.66 & 1.98 & 0.852 & 0.700 & 14.443 & 38 & 46 & 16 & Sandy clay \\
\hline
\end{tabular}

The soil of Erer is sandy clay in distribution and known by its salinity nature (table 1). The EC of the sample was 2.746 $\mathrm{mmhos} / \mathrm{cm}$ which was in salinity range. The organic matter which was 2.8 , total nitrogen and available $\mathrm{p}$ (ppm) were very low when compared with the standard.

Table 2. Effect of Soil and Water conservation structure on Growth Parameter of Sorghum.

\begin{tabular}{|c|c|c|c|c|c|c|c|}
\hline \multirow{2}{*}{$\mathbf{S} \mathbf{N}$} & \multirow{2}{*}{ Treatments } & \multicolumn{3}{|c|}{ Plant height (cm) } & \multicolumn{3}{|c|}{ Panicle length $(\mathrm{cm})$} \\
\hline & & Year 2017 & Year 2018 & Year 2019 & Year 2017 & Year 2018 & Year 2019 \\
\hline 1 & Control & $125.9^{\mathrm{b}}$ & $100.3^{\mathrm{bc}}$ & $97.467^{\mathrm{d}}$ & $17.47^{\mathrm{ab}}$ & $16.33^{\mathrm{bc}}$ & $16.33^{d}$ \\
\hline 2 & Open ended & $137.5^{\mathrm{ab}}$ & $118.6^{\mathrm{ab}}$ & $125.067^{\mathrm{ab}}$ & $16.27^{\mathrm{b}}$ & $18.73^{\mathrm{ab}}$ & $21.267^{\mathrm{ab}}$ \\
\hline 3 & Soil bund & $132.8^{\mathrm{ab}}$ & $130.7^{\mathrm{a}}$ & $121.8^{\mathrm{abc}}$ & $16.27^{\mathrm{b}}$ & $20.53^{\mathrm{a}}$ & $20.4^{\mathrm{abc}}$ \\
\hline 4 & Contour ridge & $136.2^{\mathrm{ab}}$ & $102.9^{\mathrm{bc}}$ & $132.867^{\mathrm{a}}$ & $18.27^{\mathrm{ab}}$ & $20.2^{\mathrm{a}}$ & $22.133^{\mathrm{a}}$ \\
\hline 5 & Closed ended & $149.2^{\mathrm{ab}}$ & $112.7^{\mathrm{abc}}$ & $110.6^{\text {bcd }}$ & $18.93^{\mathrm{ab}}$ & $21.53^{\mathrm{a}}$ & $18.667^{\mathrm{bcd}}$ \\
\hline 6 & Broad bed \& furrow & $153.7^{\mathrm{a}}$ & $101.7^{\mathrm{bc}}$ & $116.8^{\mathrm{abc}}$ & $19.67^{\mathrm{a}}$ & $15.87^{\mathrm{bc}}$ & $19^{\text {bcd }}$ \\
\hline 7 & Semi-circular & $143.7^{\mathrm{ab}}$ & $108.9^{\mathrm{abc}}$ & $122.867^{\mathrm{ab}}$ & $19.6^{\mathrm{a}}$ & $18.93^{\mathrm{ab}}$ & $19.4^{\mathrm{abc}}$ \\
\hline \multirow[t]{3}{*}{8} & Mulching & $139.6^{\mathrm{ab}}$ & $96.1^{\mathrm{c}}$ & $103.2^{\mathrm{cd}}$ & $18.93^{\mathrm{ab}}$ & $14.93^{\mathrm{c}}$ & $18^{\mathrm{cd}}$ \\
\hline & LSD & 22.45 & 22.05 & 19.011 & 2.69 & 3.485 & 2.96 \\
\hline & $\mathrm{CV}(\%)$ & 9.2 & 11.6 & 9.33 & 8.6 & 10.8 & 8.71 \\
\hline
\end{tabular}

\subsection{Plant Height}

The effect of physical soil and water conservation structure showed that there was highly significance difference on sorghum plant height at 5\% significance level, during last three growing season. In 2017 the highest plant height (153.7 $\mathrm{cm})$ was recorded from the treatments with broad bed \& furrow, this was because of low soil fertility disturbance (slight excavation). While the lowest plant height $(125.9 \mathrm{~cm})$ was recorded from treatment that didn't receive any conservation measure or control. This finding is in line with [13] that, taller sorghum was observed on the ridges and furrow while the lowest height on the flat land. In 2018 the highest plant height $(130.7 \mathrm{~cm})$ was recorded from treatment with soil bund, but this was in statistically parity with the rest of treatment except treatment with broad bed \& furrow, mulching and control, while the lowest plant height (96.1 $\mathrm{cm}$ ) was recorded from treatment with mulching. In 2019 the highest plant height $(132.8 \mathrm{~cm})$ was recorded from the treatment with contour furrow, this was due to the increased water holding capacity and soil fertility level across the year. While the lowest plant height $(97.467 \mathrm{~cm})$ was recorded from the control treatment. The result of the current study was in line with the finding of [7] and [9] scholars. They indicated that, conservation practices increases the plant height of the crop significantly $(p<0.05)$. Increasing all the agronomic data during the dry season The hypothesis behind this finding is that the extra moisture conserved due to the conservation measures can prominently contribute for better uptake of nutrients by the plant for facilitating the photosynthesis, fertilization of flowers, seed setting, protein synthesis, and nitrogen metabolism activities within the plants tissues, which would in turn improve the physical stand and yield of crops in general.

\subsection{Panicle Length}

The panicle length of sorghum was highly influenced by moisture conservation measures. There was high significance difference on sorghum panicle length at 5\% significance level during three growing season. In 2017 the highest plant panicle length $(19.67 \mathrm{~cm})$ was recorded from the treatments with broad bed \& contour furrow, while the lowest panicle length $(16.27 \mathrm{~cm})$ was recorded from treatment with open ended tied ridge and soil bund respectively.

In 2018 the highest panicle length $(21.53 \mathrm{~cm})$ was obtained from treatment with closed ended tied ridge and contour furrow. While the lowest panicle length $(14.93 \mathrm{~cm})$ was recorded from treatment with mulching. This was because of the panicle length of the sorghum elongated as it gates enough moisture. In 2019 the highest panicle length (22.133 $\mathrm{cm}$ ) was recorded from treatment with contour furrow, followed by open ended tied ridge. This was because of enhanced nutrients and moisture. While the lowest plant height $(16.33 \mathrm{~cm})$ was recorded from control treatment. This study was in agreement with study of [13] as he stated that, there was significant sorghum growth parameter (plant height, panicle length) because of conservation measures methods such as soil bund, contour ridges and tide ridging. 
Table 3. Effect of soil and water conservation measures on yield and yield and biomass of sorghum.

\begin{tabular}{|c|c|c|c|c|c|c|}
\hline \multirow{2}{*}{$\mathbf{S} \mathbf{N}$} & \multirow{2}{*}{ Treatments } & \multicolumn{2}{|c|}{ Biomass in $\mathrm{kg} / \mathrm{ha}$} & \multicolumn{3}{|c|}{ Yield in kg/ha } \\
\hline & & Year 2018 & Year 2019 & Year 2017 & Year 2018 & Year 2019 \\
\hline 1 & Control & $2500^{\mathrm{e}}$ & $3667^{\mathrm{e}}$ & $707.3^{\mathrm{bc}}$ & $697.8^{c}$ & $1125^{\mathrm{c}}$ \\
\hline 2 & Open ended & $6805.6^{\mathrm{ab}}$ & $9981^{\mathrm{ab}}$ & $1090.7^{\mathrm{a}}$ & $1244.3^{\mathrm{ab}}$ & $2000^{\mathrm{ab}}$ \\
\hline 3 & Soil bund & $5757.6^{\mathrm{b}}$ & $8444^{\text {bc }}$ & $557.3^{\mathrm{c}}$ & $874.8^{\mathrm{bc}}$ & $1398.8^{\mathrm{bc}}$ \\
\hline 4 & Contour furrow & $7941.9^{\mathrm{a}}$ & $11648^{a}$ & $695.7^{\mathrm{bc}}$ & $1324.9^{\mathrm{a}}$ & $2130.9^{\mathrm{a}}$ \\
\hline 5 & Closed ended & $5517.7^{\mathrm{bc}}$ & $8093^{\text {bc }}$ & $683.7^{\mathrm{bc}}$ & $856.3^{b c}$ & $1375^{\mathrm{bc}}$ \\
\hline 6 & Broad bed & $6224.7^{b}$ & $9130^{b}$ & $935.7^{\mathrm{ab}}$ & $875.6^{\text {bc }}$ & $1404.8^{\mathrm{bc}}$ \\
\hline 7 & Semi-circular & $4457.1^{\mathrm{dc}}$ & $6537^{\mathrm{cd}}$ & $869.7^{\mathrm{ab}}$ & $843.7^{\mathrm{c}}$ & $1351.2^{\mathrm{c}}$ \\
\hline \multirow[t]{3}{*}{8} & Mulching & $3055.6^{\text {de }}$ & $4481^{\text {de }}$ & $1097.3^{\mathrm{a}}$ & $768.1^{\mathrm{c}}$ & $1232.1^{\mathrm{c}}$ \\
\hline & LSD & 1692.1 & 2481.7 & 311.2 & 391.7 & 628.1 \\
\hline & CV $(\%)$ & 18.29 & 18.3 & 21.4 & 21.9 & 23.9 \\
\hline
\end{tabular}

\subsection{Biomass}

The result revealed that, there was highly significance difference among the treatments on sorghum biomass at significance level of $5 \%$ during three growing season. In 2018 the highest biomass $(7941.9 \mathrm{~kg} / \mathrm{ha})$ was recorded from the treatments with contour furrow, this was in statistically parity with open ended tied ridge treatments, while the lowest biomass $(2500 \mathrm{~kg} / \mathrm{ha})$ was recorded from control treatment. In 2019 the highest biomass $(11648 \mathrm{~kg} / \mathrm{ha})$ was recorded from treatment with contour ridge, this was in statistically parity with open ended tied ridge treatments, while the lowest biomass $(3667 \mathrm{~kg} / \mathrm{ha})$ was recorded from control treatment. Ridges have been found to be very efficient in storing the rain water, which has resulted in substantial grain yield and biomass increase in some of the major dry land crops such as sorghum, maize, wheat, and mung beans in Ethiopia [4]). Similarly reported that contour ridge and tied ridges are increase dry biomass and yield of sorghum due to improved and stored soil moisture within the root zone [5].

\subsection{Grain Yield}

The grain yield of sorghum was highly influenced by contour furrow, at significance level of $5 \%$ during three growing season. In 2017 the highest grain yield (1097.3 $\mathrm{kg} / \mathrm{ha}$ ) was recorded from the treatments with the mulch followed by open ended tied redge. This situation indicated that, there was the slight top fertile soil disturbance and enhanced water holding capacity of the soil during the first year of experimentation, when compared to that of rest treatments. This was in statistically parity with the rest treatments except soil and control, while the lowest grain yield $(557.3 \mathrm{~kg} / \mathrm{ha})$ was recorded from treatment with soil bund (Table 4). It was because of huge amount of the top fertile soil was excavated during the construction, to achieve the maximum designed bund height.

This have conformity with finding reported that different agricultural water conservation methods (mulching, ridges, supplementary irrigation) saved limited moisture and improved grain yield per hectare in drought prone agro ecological zone [18]. In 2018 and 2019 the highest grain yield $(1324.9 \mathrm{~kg} / \mathrm{ha}$ and $2130.9 \mathrm{~kg} / \mathrm{ha}$ respectively) was obtained from treatment with contour furrow, this was because of the well-established contour furrow across the slope accumulate the moisture in the soil and enhanced nutrients because of the structure. It was in statistically parity only with the open ended and closed ended tied ridge treatments, since they have nearly related catchments in which they can store moisture. This was because of the increased moisture holding capacity of the soil and enhanced essential nutrients by contour furrow conservation measure. While the lowest grain yield $(697.8 \mathrm{~kg} / \mathrm{ha}$ and $1125 \mathrm{~kg} / \mathrm{ha})$ was obtained from control (table 3). This was in line of agreement with [5] and [7]. Which stated as, insitu soil moisture conservation techniques such as contour furrow and tied ridges improved soil moisture stored within the root zone as compared to the control, resulting in higher grain yield of sorghum. And Similarly, reported that, contour furrow and other tied ridges has resulted in above $130 \%$ higher in grain yield compared to flatbed planting (control) and also under ridges the average grain yield ranged from 50 to over 100 percent when compared with traditional practice

Table 4. Effect of different insitu conservation measures on economic sorghum productivity.

\begin{tabular}{|c|c|c|c|c|c|c|c|}
\hline Treatments & Yield kg/ha & TR (ETB/ha) & TVC (ETB/ha) & TFC (ETB/ha) & TC (ETB/ha) & NI (ETB/ha) & $\mathrm{B} / \mathrm{C}$ \\
\hline No conservation) & 1125 & 12,375 & 1125 & 2680 & 3805 & 8,570 & 2.2 \\
\hline Open ended & 2000 & 22,000 & 1350 & 2680 & 4030 & 17,970 & 4.5 \\
\hline Soil bund & 1398.8 & $15,386.8$ & 1350 & 2680 & 4030 & 11,356 & 2.8 \\
\hline Contour Furrow & 2130.9 & $23,439.9$ & 1350 & 2680 & 4030 & $19,409.9$ & 4.8 \\
\hline Closed E & 1375 & 15,125 & 1800 & 2680 & 4480 & 10,645 & 2.6 \\
\hline Broad B & 1404.8 & $15,452.8$ & 1125 & 2680 & 3805 & $11,647.8$ & 3 \\
\hline Semi cercular & 1351.2 & $14,863.2$ & 1125 & 2680 & 3805 & $11,058.2$ & 2.9 \\
\hline
\end{tabular}

Key* where, $\mathrm{TR}=$ total revenue, $\mathrm{TVC}=$ total variable cost, $\mathrm{TC}=$ total fixed cost, $\mathrm{TC}=$ total cost, $\mathrm{NI}=$ net income and $\mathrm{B} / \mathrm{C}$ benefit cost ratio

The detail evaluation of the economic analysis of treatments shows that, the direct impact of moisture saving in generating NI was very high for a hectare of land per season. Which means very high value from hectare. Maximum total 
cost (ETB) was incurred by control treatment whereas the minimum variable cost (ETB) was obtained by semicircular. Benefit cost ratio (BCR) of each treatment was computed as the ratio of NI earned to the TC expended. Accordingly, maximum BCR (4.8) was obtained by contour furrow conservation measure. However, the lower BCR was recorded by treatments without conservation measures and mulching respectively. This implies that, minimum yield was obtained by those treatments and they were not economically more viable. From this economic analysis contour furrow was the most economically viable types of conservation measure for sorghum production in the low land area's, followed by open ended tied ridges $(19,409.9$ ETB and 17,970) respectively. Therefore, farmers in the study area were benefited when they apply contour furrow and open ended tied ridges, rather than absolute control (no conservation measures). And the experiment with contour furrow and open ended tied ridges treatments were economically profitable.

\section{Conclusion}

Physical soil and water conservation structure in moisture stress area improve the soil moisture at the root zone due to improved soil infiltration and cached runoff at the rain fall time which increase the crop stand, biomass and grain yield of early matured sorghum in the study area. Contour furrow, open ended tied ridges, and broad bed were significantly increase the plant height, panicle length, above ground biomass and grain yield of sorghum and reduce soil loss. This is because of an extra moisture stored as the result of the design.

Physical soil and water conservation practices are absolutely necessary in agricultural operations for successful sorghum production and improve productivity in such Erer site of moisture stressed area. More over Contour furrow and open ended tied ridges are promising physical structure in the study area at improving the biomass of sorghum crop and grain yield due to improved soil moisture in the soil and at root zone. Generally, it is necessary more or repeated research for validity and conformity to consider and quantify the soil loss and soil moisture at different growing stage of crop as well as to determine its adoptability analysis. Farmers in the study area were benefited when they apply contour furrow and open ended tied ridges, rather than absolute control (no conservation measures). Farmers in the study area can be benefited or obtain (17,759.9 ETB) and (16320 ETB) when they apply contour furrow and open ended tied ridges respectively, rather than absolute control (no conservation measures). And the experiment with contour furrow and open ended tied ridges treatments were economically profitable.

\section{Recommendation}

Farmers of Babile district should use contour furrow conservation measures for sorghum production. Farmers around Erer PA's, who's their farm soil are sandy clay loam in textural distribution, should practice or use contour furrow and and open ended tied ridges as physical soil and water conservation structure respectively. Office of agriculture and other NGO's should create awareness for farmers on use of appropriate soil and water conservation measures which could fit with the physical properties of the soil. Farmers can be benefited or obtain (17,759.9 ETB) and (16320 ETB) when they apply contour furrow and open ended tied ridges respectively, rather than absolute control (no conservation measures).

\section{Acknowledgements}

I would like to acknowledge Fadis agricultural research center for they allow us all facility for the research accomplishments.

\section{References}

[1] Critchely W, Siegert K, Champman C (1991) A manual for the design and construction of water harvesting schemes for plant production. Food and Agriculture Organization of the United Nations (FAO), Rome. http://www.fao.org/docrep/U3160E/u3160e00.HTM

[2] FAO AGL (2006). Crop water management: Soybean. Agriculture, Land, and Water (AGLW) Management Group, Land and Water Development Division, Food and Agricultural Organization (FAO), Rome, Italy. water-management@fao.org

[3] FAO. 2001. Guidelines and reference materials for promoting integrated soil and nutrient management in Farmer Field Schools. Reference material for the module on Tillage. Land and Water Development Division. Rome.

[4] Georgis K, Takele A. 2000. Conservation farming technologies for sustaining crop production in semi-arid areas of Ethiopia. In Conservation Tillage for Dryland Farming. Technological options and experiences in Eastern and Southern Africa, eds. E. K. Biamah; J. Rockstrom; G. E. Okwach. RELMA, Workshop Report No. 3, 142-147.

[5] Karrar, A. B., et al. "Effects of some in-situ water harvesting techniques on soil moisture and sorghum (Sorghum bicolor (L.) Moench) production in northern Gedaref state." Glob $J$ Plant Ecophysiol 2 (2012): 54-66.

[6] Kidane, G., 1982. The influence of some tillage methods and spacing on soil moisture regimes and their effects on growth and development of sorghum. An M.Sc. Thesis presented to the School of Graduate Studies of Alemaya University.

[7] Milkias, Amisalu, Teshale Tadesse, and Habtamu Zeleke. "Evaluating the effects of in-situ rainwater harvesting techniques on soil moisture conservation and grain yield of maize (Zea mays L.) in Fedis District, Eastern Hararghe, Ethiopia." Turkish Journal of Agriculture-Food Science and Technology 6.9 (2018): 1129-1133.

[8] Moroke, T. S., Schwartz, R. C., Brown, K. W., and Juo, A. S. R. (2005). Soil water depletion and root distribution of three dry land crops. Soil Science Society of America Journal, 69, 197-205. 
[9] Mudalagiriyappa BK, Ramachandrappa HV, Nanjappa HV (2012) Moisture conservation practices and nutrient management on growth and yield of rabisorghum (Sorghumbicolor) in the vertisols of peninsular India. Agric Sci 3 (4): 588-593. https://doi.org/10.4236/as.2012.34071

[10] Pal, U. R. and Murari, K. (1985). Length $\times$ width measurement for estimating leaf area of grain sorghum. Samaru Journal of Agricultural Research, 3, 109-112.

[11] Patil SL, Sheelavantar MN (2003) Effect of cultural practices on soil properties, moisture conservation and grain yield of winter sorghum (Sorghum bicolar L. Moench) in semi-arid tropics of India. Agric Water Manag 64 (1): 49-67. https://doi.org/10.1016/S0378-3774(03)00178-1.

[12] Ramesh, T. and Rathika, S. (2009). Land configuration techniques for rain fed Alfisols ecosystem- review. Green Farming 2 (12), p. 879-881.

[13] Stern, R. D., Dennett, M. D., and Dale, I. C. (1982). Analysing daily rainfall measurement to give agronomically useful results, 1: Direct methods. Experimental Agriculture, 18, 223 236.
[14] Tilander, Y. and Bonzi, M. (1997). Water and nutrient conservation through the use of agroforestry mulches, and sorghum yield response. Plant and Soil, 197, 219-232.

[15] Waghmare, A. B., Krishnan, T. K., and Singh, S. P. (1982). Crop compatibility and spatial arrangement in sorghum-based intercropping systems. Journal of Agricultural Science (Cambridge), 99, 621-629.

[16] Uwizeyimana, D., et al. International Soil and Water Conservation Research (2018), https://doi.org/10.1016/j.iswcr.2018.03.002i.

[17] Yitebitu Moges. 2004. Innovations in dryland farming techniques. Consultancy Sub-report No. 5. FARM Africa/SOS Sahel.

[18] Zougmore, R., Mando, A., and Stroosnijder, L. (2004). Effect of soil and water conservation and nutrient management on the soil-plant water balance in the semi-arid Burkina Faso. Agricultural Water Management, 65, 103-120. 